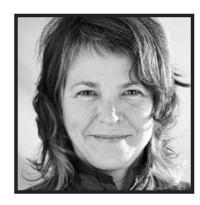

\title{
The Story of Summer Visions: The Creation of a New Public in a Community-Engaged Youth Media Program
}

Patti Fraser, Simon Fraser University

\begin{abstract}
Over the course of the last two decades, youth media programs have become increasingly popular as models for community-engaged digital storytelling projects. This narrative reflection is based on the author's experience as the creative mentor and story editor within a nationally recognized youth-run media production program. Drawing on Arendt's (1954) thinking on the educative project and on Poyntz's (2009) argument that holds "agonistic struggle" over creative expression within a community of youth engagement is critical to developing a shared sense of the world. This narrative reflects on the collective work of story creation within a community-engaged media art practice as a vehicle for developing capacity to hold pluralistic points of view, perspective, and voice essential for the sustainment of democratic movements.
\end{abstract}

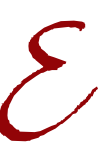

very morning in late June, when the world was still green with summer hope, I would take a morning walk to the local high school. In the bright surreal quiet you could make out the sound of the odd sprinkler attempting to water the dry ragged little yards along the way. The street is momentarily at ease from the grimly determined and the lethargic ploddings of high school students who carve a path along this route to the school a few city blocks away. 
This morning I walk towards a group of sleepy teenagers hanging outside a back door of the school. As the odd and singular adult in the group I join them. We stand together like a group of condemned prisoners waiting for the doors to be unlocked before we enter. Waiting for the sour air of hallways and half-empty lockers to hit us as we make our way to a large windowless studio down the dim echoing hall. Every year for the past decade as I greet the new groups of young people who are the participants and digital video production mentors, I quell my yearnings for beachside-swimming and blue-sky-staring. And prepare to begin again with this summer's iteration of the Summer Visions Film Institute.'

Every year they look more awkward and more tentative than the last. And yet by summer's end, I'm guessing these same awkward souls will feel like they own this place. In the chaos of the next few weeks of this youth-run media institute, the hallways are transformed into other places: a jail, a discotheque, an office, the interior of the United Nations, or someone's bedroom; these folks will stop being students. They will turn into film producers, overtaking this school and its habitual associations with their own imaginings.

There are only three sets of keys handed out each summer by the nervous school administration. I don't possess a set because I'm not in charge. A small cadre of youth who were past years' participants, are now video and film production mentors and the Institute's summer directors. ${ }^{2}$ They are generally between 18 and 22 years of age. They will share the precious sets of keys and the responsibilities of the ambitious program that will be responsible for the maintenance of tens of thousands of dollars' worth of production equipment and oversee the activities of 12 youth digital production mentors as well as the 150 participants who come to make films. All of them will play some role in making 30 short films. Many of the directors and mentors have been working alongside Corin Browne ${ }^{3}$ and I for a number of years.

Eighty percent of the young people who attend every year will be on full scholarship due to financial need. The 30 films produced in the summer will be screened for the public in the fall in The Pacific Cinematheque Theatre in downtown Vancouver.

On this morning when the school doors open, the regular school bells have been dismantled and music is pumping through the PA system. Glancing for one moment longer at the bright quiet green of the summer, I'm already struggling to hear above the noise. 
In the years I have walked this summer walk, a part of my practice as a communityengaged media artist was to model for the youth mentors and the participants notions of hospitality. ${ }^{4}$ There were very few rules in place when we first started. One young man arrived every day to sleep on the old couch in one of the studios because we knew he had trouble at home or had been out all night. Once a camera was stolen and then brought back. Another camera was run over by a car in a complicated film shoot. The hundreds of thousands of dollars in equipment-begged, borrowed, rented-was put at the disposal of everyone there with the understanding of responsibility implicit in the opportunities to use and experiment with the equipment. It was initially nerve-racking for the few adults associated with the Institute to observe teenage production mentors guide even younger or less experienced or less socialized adolescents with thousands of dollars of rented or donated gear. I learned early on to look away and to trust. As it turned out, especially in the early years of the Institute, despite the economically marginal lives of many of the youths, and despite the needs this culture created with its own set of challenges and demands, theft wasn't one of them.

The core founders emphasized the success of the work by the degree of hospitality, respect, and co-operation enacted within the program. This engagement was founded on working collaboratively within a creative process. Everyone was expected to contribute to the production of a short film. The youth mentors were responsible for ensuring that all the participants had roles to play and that no one was left out. The work was difficult and challenging. The Institute was often a hard place to be in.

I was hired as a story mentor to guide the development of the stories the youth created. The role we viewed story creation playing within this media production program was seen as more important than the learning associated with the media technology. Through story we were able to offer critical challenges to the participants, which in turn, helped them in imagining something beyond the replication of popular culture and mass media that captured so many of their imaginations. We considered the creation of story as a way to make meaning out of the events of our lives. When asked to co-create story within small production teams, the work initiated energetic interactions that were sometimes fraught with difficult tensions within the group. These tensions made demands on the imaginations of the youth who were invested in creating the stories or ideas for the films. They had to endure the imaginations of each other and the youth video mentors as well as incorporate and tolerate the ideas of the directors and myself in order to be able to move on towards the making of their work. This struggle most often proved to be the most challenging and difficult part of the production program, but after the first few 
years of this model of youth-run engagement, I began to understand how critically necessary the tensions and creative interactions were in the making of the storyand in how these tensions played into the success of the films and into the sense of shared responsibility and achievement the participants enjoyed at the end of the production. Beyond that, and more importantly, was the camaraderie these youth shared with each other.

Poyntz (2009) writes specifically about Summer Visions Film Institute as the locale of his dissertation research and his research on youth media education and democratic movements. He asserts youth media production and mentorship programs like Summer Visions Film Institute for Youth contribute to the formation of the creation of "new publics." Poyntz sees Arendt's (1954) notion of education as critical to his theorizing. Poyntz (2008) writes about the program of work at the Institute not being so much about "presenting in straightforward formulation positions about specific political projects, but rather garnering opportunities for thoughtfulness" (p. 70). Arendt (1954) asserts that these new publics emerge through challenges to our sense of a shared world by the opening up of possibilities to see and hear from individuals who are different. Poyntz (2008) furthers this argument by asserting that it is through working in pluralistic and in public acts of "agonistic" struggle that allows for groups to be "both be with and assert oneself to others" (p. 61). This struggle characterizes the tensions that take place when ideas are being creatively and collaboratively generated. The creative encounters and tensions that Poyntz characterizes as an agonistic struggle took place during the story creation period between youth producers, participants, and the adult mentoring artists. By being with others and by asserting oneself in public, one preserves one's freedom in Arendt's (1954) view by fostering pluralistic points of view, perspective, and voice. Freedom is in this sense not about freedom of choice, but "the freedom to call something into being which did not exist before" (p. 150).

In Arendt's view, action that places one in relationships with others in ways that interrupt discourses of power and processes of habit constructs our sense of reality (Curtis, 1999). This dynamic of interrupting discourses of power through socially engaged art practice is, in art critic Grant Kester's (2000) view, an expression of aesthetic relations and belongs to the lineage and practices of many socially engaged art practices.

It was through this robust engagement over stories within the Institute that we worked to critically examine values and perceptions. It was demanding dialogic work. Drawing on Arendt's (1954) thinking in the Human Condition, the community- 
engaged media arts practice we facilitated at Summer Visions Film Institute could be considered a political practice because it expanded and challenged our habituated constructs of reality by bringing us into contact with others in a robust tension.

While the creation of story could be seen through the lens of an Arendtian perspective as a political and philosophical project, it was foremost an imaginative project, one that sought new meanings. And it went without saying that story development remained our biggest challenge at Summer Visions Film Institute; a balancing act that attempted to foster originality and meaning while reaching beyond the sensibilities many of the participants had inherited through mass media culture. One of the strategies we used to help the emerging filmmakers tackle co-creating original stories was to invite the entire group to brainstorm what they wanted to make their films about. After the entire group had had a chance to see the imaginative reach and some of the potential that resided inside the entire group, I would invite a dialogue around what was trying to speak to us through these story ideas. We asked people to self-select into small creative teams that would then take the emergent themes and ideas and start to shape them into story.

We encouraged stories that came from their lived experience and sought opportunities for them through story to comment on their shared experience of culture or age. And we devoted a large amount of the program's time to unpacking the themes and ideas by encouraging the writing of story, allowing them to entertain the idea that through writing other voices emerge.

The tensions that arose in the development of story were what Poyntz (2009) saw as the "agonistic" struggle of publicity and the ensuing opportunities for thoughtfulness. As story lines developed that may have included, for example, unexamined instances of sexism or racism, it was up to the youth production mentors to challenge the story and to help move the discourse around these issues through story. By creating the story within production teams, these teams became locales of critical thinking as each day the short pieces were refined and made ready for production. The emphasis this Institute gave to story development was a way to critically address the overwhelming confidence most of the participants had placed in the technologies of production, and in the belief that technology was the answer to their creative dilemmas. The idea that technology could supplement or replace meaning that comes from the hard work of construction of story or critical thinking in the development of an idea was critically challenged throughout the production process. 
This work often entailed an intuitive attempt to chart what the collective intention of the room was trying to express. By encouraging the creators to wait and be patient and to make space with the hope that something new and something other would emerge, we were asking the young filmmakers to engage in trusting in the making of communal meaning. It was about taking on the role of what director and creator Steven Hill ${ }^{5}$ called "becoming the author of the room." By acting as a point of tension and critical eye, we at the Institute were attempting to create a pedagogical experience born from Arendt's notion of the educative act. We took to heart Arendt's (1954) invitation to educators to care for the next generation of youth and children enough so as to invite them into the world's renewal, not as we imagined it should be, but how they will come to embody and imagine it into being. Which was, in essence, to consider working with a world in paradox. In generating a creative struggle or creative tension through their shared work with us at the Institute, we engaged in the struggle to make sense of the world as they understood it, and in doing so, helping them prepare a future for the world that is and always will be "out of joint" (p. 189).

Through challenging the ideas of the youth through the stories they made, as educators we could initiate a route to critical thinking that does not seek resolution, nor instruct them on what those resolutions for the world's problems might be. As Poyntz (2009) theorizes, within Arendt's thinking on education, by continually asserting that within the educative project where there is a resolution to the problems of the world, we are in fact removing the next generation's youth from their own future role in the body politic (p. 6). By making the demand to attempt to create original stories or ideas upon which to base their films and by asking the youth to do this work collaboratively, we were asking these young people to use their imaginations to produce forms of communal meaning and to step beyond the assertions of individuality and, in many cases, beyond the voices that initially spoke the loudest and with the most confidence in the room.

As the years progressed at the Institute, the culture of the place changed. The adult administration and funders sought different outcomes and had different ideas about what the Institute's goals should be. Notions of creative uncertainty and the development of democratic community-engaged work was in many ways counter to a growing body of administrators and funders who saw the program as a stepping-stone to industry training or as a summer camp experience. As the perceived "success" of this program increased, the playfulness and creativity of the youth directors decreased. A shared sense of freedom was outweighed by an increasing sense of responsibility. 
With this change came the change in the morning walk through the neighborhood in east Vancouver. Over the course of the decade, the ragged little yards were improved. The houses took on fresh coats of paint and the addition of rental suites. Newer models of cars started to fill the streets. Early morning quiet was replaced by the relentless advance of home improvement erupting earlier and earlier. And year by year, the film Institute gained recognition from outside the neighborhood. Those young people first to enroll started to come from different demographics and from farther away from the culture of this neighborhood and these streets. Even the novelty of using models of digital video production as a forum for creation and learning with youth was becoming redundant as current technologies overran older forms. Self-producing a film was no longer a radical idea, and as in all stories, something inevitably came to its end. The year I received my last nametag as a Pre-production/Instructor, I saw it as an indicator that this was to be the last year of my morning walks when the world was still green with summer hope.

But that was then and this is now. Now I'm asking the past to speak to the future. As a researcher with the Art for Social Change Research ${ }^{6}$ project, I'm asking myself as well as other community-engaged artists what needs to be preserved or held as responsibility as it is reimagined in the future?

Perhaps what matters most in the question posed to the artists can be best summed up by the simple task of trying to remember how to make meaning out of the uncertainty of our lives? How to create an antidote to bewilderment and confusion of this world which is and always will be out of joint and waiting for the future to arrive? And in helping the next generation move towards a future that remains still green with summer hope.

\section{Acknowledgment}

The author acknowledges support of the Social Sciences and Humanities Research Council of Canada and Simon Fraser University's Art for Social Change Project. 


\section{Notes}

1. Summer Visions was organized initially through a partnership between Dream Big Film and the Television program at Templeton Secondary and Pacific Cinematheque, a local film Institute. It operated in a converted high school automotive studio and targeted low-income or other youth identified as marginalized primarily for Vancouver's East side and subsequently across Lower Mainland of British Columbia.

2. The mentors and directors of the Summer Visions Film Institute are chosen from youth from the surrounding area who exhibited a willingness to experiment with the guiding principles of a community-engaged art project.

3. Corin Browne is a founding member of The Summer Visions Film Institute for Youth.

4. Hospitality, beyond including food, drinks, accommodation, and a welcoming space, requires more of us, individually and collectively. Wardrop and Fels (2015) write, "Hospitality, the ability to welcome those who we have not been expecting nor invited, requires transition from habits of language, actions, assumptions, and expectations into an action space of inquiry, curiosity, fluidity, adaptation, improvisation, in order to create a language and practice of shared resonance, embodied awareness, and reciprocal listening.... Who will we become in the presence of each other?" (p. 64). The stranger, may in the end, be myself, seeking to create meaning in an environment where hospitality is located beyond name tags and labels, within a shared relational venture of imagination.

5. Steven Hill speaks to being the author of the room in his interview for Simon Fraser University's Arts for Social Change Research Project funded by the Social Science and Humanities Research Council of Canada (www.icasc.ca/artfor).

6. This question is based on Hannah Arendt's thinking as it relates to the education of the young. Through my role as a research associate within the Art for Social Change Research Project, a multi-year national research project funded by the Social Science and Humanities Research Council of Canada, Dr. Lynn Fels and I arrived at a question while asking senior artists what might characterize their art practice, with an eye to future practitioners. 


\section{References}

Arendt, H. (1954). Between past and future: Eight exercises in political thought. Harmondsworth, Middlesex, England: Penguin Books Ltd.

Curtis, K. (1999). Our sense of the real, aesthetic experience and Arendtian politics. Ithaca, NY: Cornell University Press.

Kester, G. (1999-2000). Dialogical aesthetics: A critical framework for litoral art. Variant, 2(9)(Suppl.), 2-8.

Poyntz, S. (2008). Producing publics: An ethnographic study of democratic and youth media production mentorship (unpublished dissertation). University of British Columbia: Vancouver, BC.
Poyntz, S. (2009). 'On behalf of a shared world': Arendtian politics in a culture of youth media production. Review of Education, Pedagogy and Cultural Studies, 31(4), 365-386.

Wardrop, A., \& Fels, L. (2015). Stepping through the looking glass: Embodying hospitality through transitions. In Carter, M., Prendergast, M., Belliveau, G. (Eds.) Drama and theatre education: Canadian perspectives. Polygraph Book Series, Canadian Association of Teacher Education.

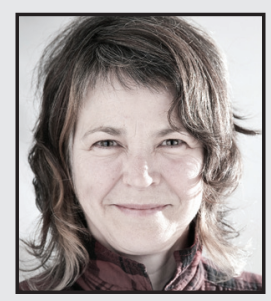

Patti Fraser is the 2013 recipient of the Vancouver Mayor's Art Award for Community Engagement. She is an artist/researcher with The Art for Social Change Research Project and Artistic Director of The Housing Matters Media Project. She is a founding member of the nationally recognized Summer Visions Film Institute for Youth. Her work has been recognized as best practices in diverse fields, within Aboriginal Education, the Canadian Council for Refugees, and the Canada Council for the Arts. She is currently working with digital video in collaboration with the Vancouver Foundation's Youth and Homelessness Initiative. 